\title{
Influence of putrefactive decomposition of sheep hooves on the cytomorphological composition and biochemical properties of blood
}

\author{
Daria Kazakova*, Sergey Kolomiytsev, and Vera Suvorova
}

Kursk State Agricultural Academy named after I. I. Ivanov, 70 Karl Marks Street, Kursk, Russia, +79996078658.

\begin{abstract}
We studied the effect of putrefactive decomposition of sheep hooves on the cellular composition, physical and chemical properties of blood, as well as on the biochemical composition of its serum. In the production conditions of the sheep-breeding complex, orthopedic medical examination and identification of sheep with putrefactive decay of the hooves were carried out. Subsequently, blood samples were collected from 10 sick sheep and 10 clinically healthy animals for general clinical analysis and biochemical analysis of their serum. The selected blood samples were analyzed on the haematological automatic analyser "Abacus vet 10" and the semi-automatic biochemical analyser "Stat fax 300". In the biochemical composition of blood serum, putrefactive decay of hooves increased the concentration of total protein by $7.94 \%$, total bilirubin by $22.08 \%$, urea by $75.18 \%$, and reduced the concentration of glucose by $17.88 \%$ relative to clinically healthy sheep. At the same time, the activity of aspartate aminotransferase, alanine aminotransferase, alkaline phosphatase, and creatine kinase in the blood serum of sheep with putrefactive hoof decay exceeded similar indicators in clinically healthy sheep by $9.65 \%, 9.16 \%, 13.70 \%$, and $19.90 \%$, respectively. In addition, the concentration of sodium, potassium, calcium, phosphorus and magnesium in the blood serum of sheep with putrefactive decay of hooves was by $15.44 \%, 9.64 \%, 3.49 \%$, $25.35 \%$ and $9.78 \%$ less than in the blood serum of clinically healthy sheep.
\end{abstract}

\section{Introduction}

The main task of animal husbandry is to provide the population of the country with high-quality food products of animal origin [1]. To solve this problem, large industrial livestock complexes are being built, which contain a large number of animals [2]. In the process of technological exploitation of animals on limited industrial areas, there is a massive spread of various surgical diseases associated with injuries [3]. In particular, in sheep there are purulent-necrotic, purulentputrefactive and putrefactive injuries of the finger tissues, which, according to various estimates of experts, are diagnosed from 38 to $83 \%$ of the animals of the main breeding stock [4-5]. Sick animals are poorly fed, do not gain the necessary live weight, reduce wool productivity, the expected fertility decreases, which leads to significant economic losses of sheep-breeding complexes. In addition, the treatment of sick sheep with purulent-necrotic, purulent-putrefactive and putrefactive finger tissue injuries is a time-consuming and expensive process [6]. In this regard, the relevance of research on the development of methods for early diagnosis of the above surgical pathologies in sheep increases. One of these methods is to assess the response of the diseased organism to the aggressive impact of technological processes and the pathogenesis of the disease by hematological and biochemical parameters [7]. Based on this, it was considered appropriate to study the effect of putrefactive decomposition of hooves of sheep on the cellular composition of blood, physical and chemical properties of blood, as well as on the biochemical composition of its serum, which served as the purpose of scientific research.

\section{Materials and methods}

The work on assessing the effect of putrefactive decay of sheep hooves on the cellular composition, physical and chemical properties of blood, on the biochemical composition of its serum was carried out. This happened in the hematology laboratory of the Department of Surgery and Therapy of Kursk State Agricultural Academy and in the production conditions of the sheepbreeding industrial complex in the Kursk region. Initially, in the production conditions of the industrial complex for the breeding of sheep of the meat direction of selection, orthopedic medical examination of the main breeding stock was performed. During the orthopedic medical examination, sick animals were identified that have a fragile and soft hoof horn with a fetid putrid smell that characterizes the putrid decay of the hooves. In the future, blood samples were taken from sick sheep in vacuum tubes for general clinical analysis and for biochemical studies of blood serum. For comparative evaluation, similar blood sampling was performed in

\footnotetext{
*Corresponding author: dari-13r@yandex.ru
} 
clinically healthy sheep. In total, 10 blood samples were collected for hematological and biochemical analyses in each category of examined animals-clinically healthy and sick sheep. The general clinical analysis of blood samples was performed on an automatic hematological analyzer "Abacus vet 10". To do this, the device was connected to the power supply, the analyzed animal type was selected on the digital display of the device, the test blood sample was placed in the test receiver and the "Start" button was pressed. Further blood analysis was performed automatically by the diagnostic device, taking into account the quantitative content of red blood cells, white blood cells, platelets, the concentration of hemoglobin, the average content of hemoglobin in the red blood cell, the hematocrit value and the rate of erythrocyte sedimentation. Biochemical blood tests included the preparation of selected blood samples before obtaining serum. Prepared blood serum samples from healthy and sick sheep were analyzed on a biochemical analyzer "Stat fax 300" according to the methods specified in the technical documentation for the diagnostic operation of this device. During the biochemical analysis of blood serum samples, the concentrations of total protein, total bilirubin, urea, glucose, the activity of aspartate aminotransferase, alanine aminotransferase, alkaline phosphatase, creatine kinase, the level of micro - and macronutrients (sodium, potassium, calcium, phosphorus and magnesium) were determined. The obtained digital indicators were subjected to statistical processing with the calculation of the degree of confidence. The digital indicators of the cellular composition, physical and chemical properties of blood, as well as the biochemical composition of its serum in clinically healthy sheep and in animals with

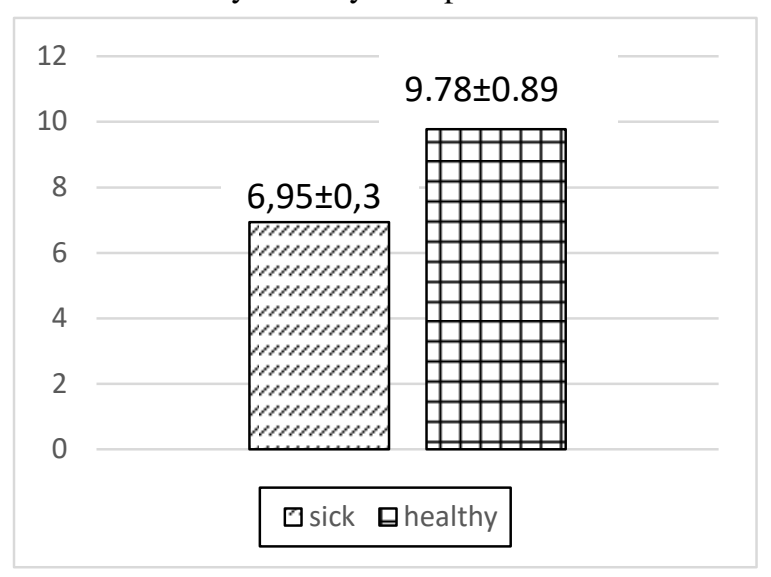

putrefactive decay of hooves were compared with each other. This happened with reference indicators of the physiological norm; we interpreted and formulated a conclusion about the effect of putrefactive decay of hooves on hematological and biochemical parameters.

\section{Results and discussion}

The results of studies of the cytomorphological composition of blood in clinically healthy sheep and in sheep with putrefactive decay of the hooves allowed us to establish that the number of red blood cells in the vascular bed of diseased animals was $6.95 \pm 0.33 \mathrm{G} / \mathrm{mkl}$, and in clinically healthy animals $-9.78 \pm 0.89 \mathrm{G} / \mathrm{mkl}$ (Figure 1).

Thus, putrefactive decay of hooves contributed to a decrease in the quantitative content of red blood cells in the blood by $28.94 \%(p \leq 0.05)$ relative to similar indicators of blood cell composition in clinically healthy animals. Counting the number of platelets showed that in clinically healthy sheep their number was $330 \pm 2.36$ $\mathrm{T} / \mathrm{mkl}$, and in animals with putrefactive processes in the hooves-306.98 $\pm 1.32 \mathrm{~T} / \mathrm{mkl}$ (Figure 2).

Thus, the development of putrefactive decay of hooves caused thrombocytopenia by $4.13 \% \quad(p \leq 0.05)$. Further consideration of the blood cell composition to determine the total number of white blood cells in patients and healthy sheep allowed us to establish the following. In the first category of animals their number in the blood vessels was in the range of $16.89 \pm 0.98$ $\mathrm{T} / \mathrm{mkl}$, and in the second category - clinically healthy animals $-9.93 \pm 1.34 \mathrm{~T} / \mathrm{mkl}$ (Figure 3 ).

Figure 1. Erythrocyte concentration in healthy and sick animals, G/mkl 


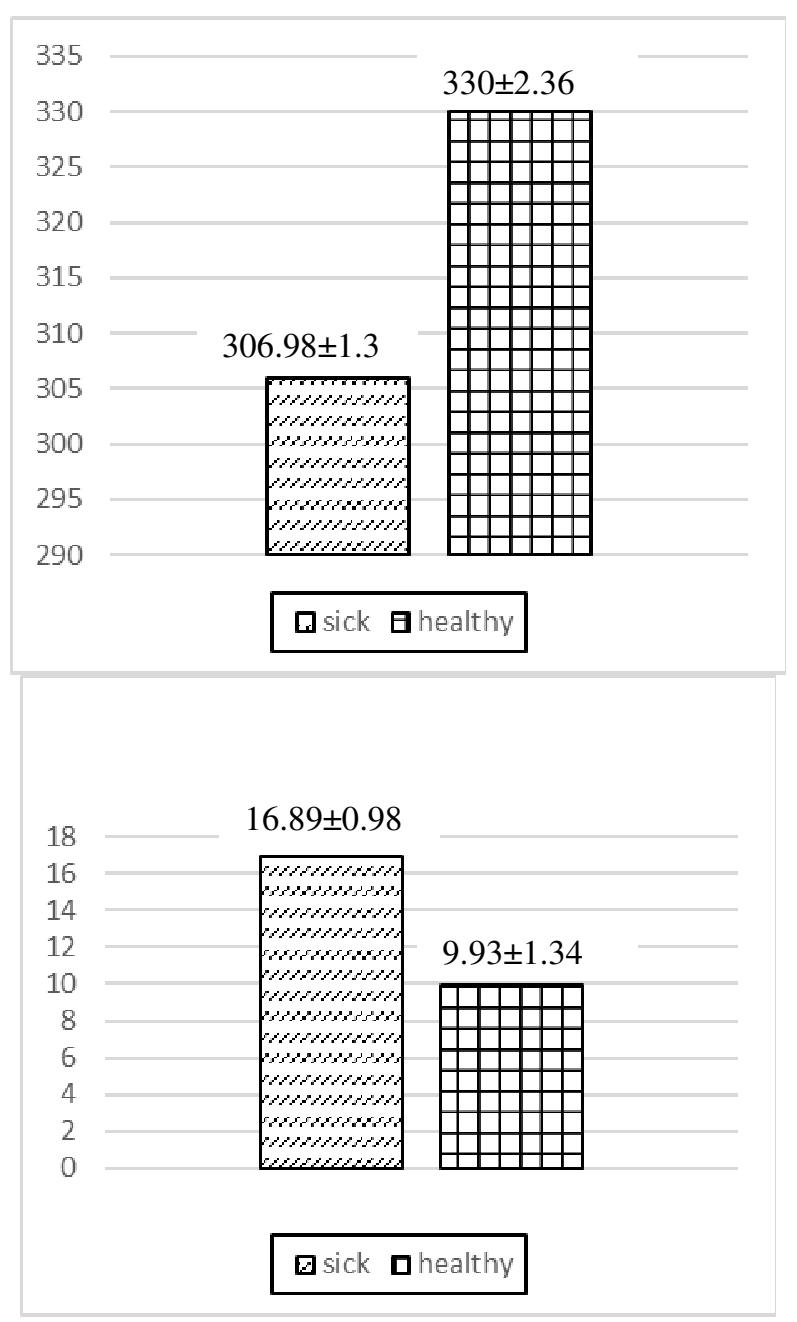

A comparative analysis of the number of white blood cells between the two categories of sheep showed that putrefactive decay of hooves provoked the development of leukocytosis by $89.13 \% \quad(\mathrm{p} \leq 0.05)$. The established cytomorphological composition of blood in clinically healthy sheep and in sheep with putrefactive decay of

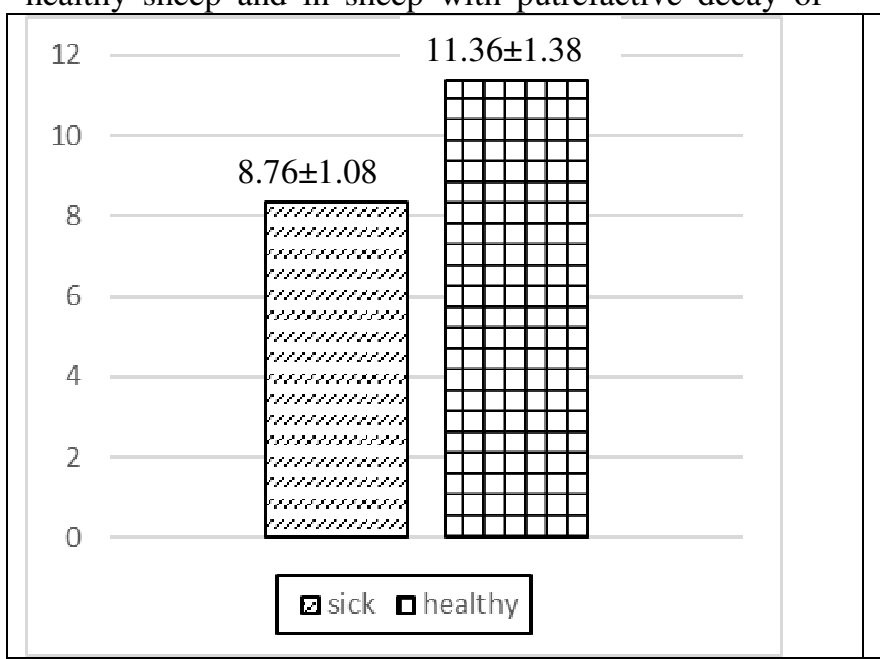

The hematocrit value in clinically healthy and sick sheep is within the limits of the reference values of the
Figure 2. Platelet concentration in healthy and sick animals, $\mathrm{T} / \mathrm{mkl}$

Figure 3. Concentration of leukocytes in healthy and sick animals, T/mkl.

hooves had a significant effect on its physical and chemical properties. Thus, the level of hemoglobin concentration in clinically healthy sheep was $11.36 \pm 1.38$ $\mathrm{g} / \mathrm{l}$, and in patients with putrefactive decay of hooves was lower by $22.88 \% \quad(\mathrm{p} \leq 0.05)$ and was equal to $8.76 \pm 1.08 \mathrm{~g} / \mathrm{l}$ (Figure 4).

Figure 4. Hemoglobin concentration in healthy and sick animals, g/l.

physiological norm; in healthy sheep it had a numerical expression equal to $38.96 \pm 1.12$, and in patients $30.16 \pm 0.96$ (Figure 5). 


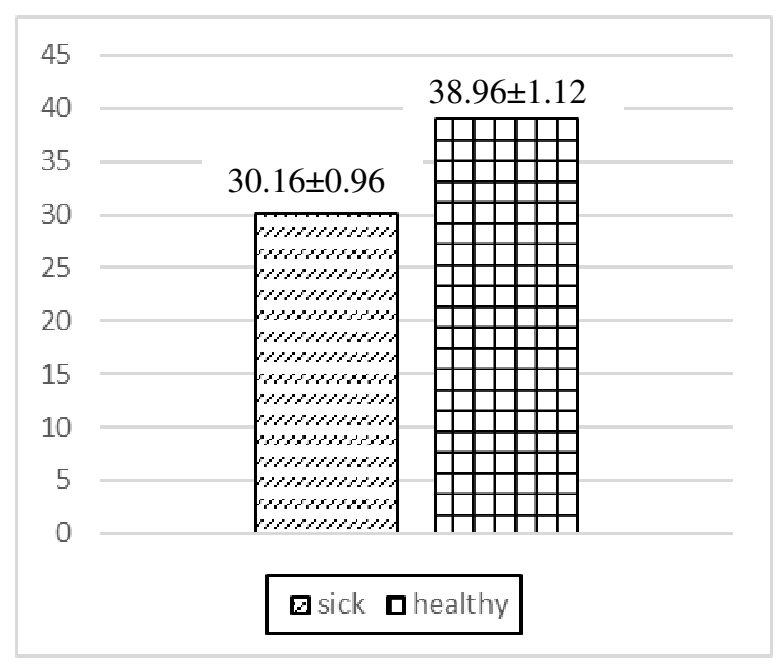

However, in sheep with putrefactive decay of the hooves, a decrease in the hematocrit index was noted by $8.80 \% \quad(\mathrm{p} \leq 0.05)$ relative to clinically healthy sheep. Further hematological analysis of the blood revealed that putrefactive decay of the hooves contributed to the development of hypochromic anemia, since a decrease in the average hemoglobin content in the red blood cell was recorded by $23.98 \%(\mathrm{p} \leq 0.05)$ than in clinically healthy animals. Thus, the average content of hemoglobin in the red blood cell in clinically healthy sheep was $9.13 \pm 0.21$ $\mathrm{pg}$, and in sick animals $-6.94+-2.34 \mathrm{pg}$. The rate of erythrocyte sedimentation in sheep with putrefactive hoof decay was $1.23 \pm 0.03 \mathrm{~mm} / \mathrm{h}$, and in clinically healthy animals $-0.85 \pm 0.15 \mathrm{~mm} / \mathrm{h}$. Thus, putrefactive decay of sheep hooves accelerated the erythrocyte sedimentation reaction by $44.70 \%(\mathrm{p} \leq 0.05)$.

Biochemical methods of blood serum analysis determined that the development of putrefactive decay of sheep hooves caused an increase in the level of total protein content by $7.94 \%$ ( $\mathrm{p} \leq 0.05)$. That is, in clinically healthy sheep, total protein in the blood serum contained $63.30 \pm 1.46 \mathrm{~g} / \mathrm{l}$, and in sick animals $-68.33 \pm 0.59 \mathrm{~g} / \mathrm{l}$. The concentration of total bilirubin in sheep with putrefactive decay of hooves exceeded the upper limits of the physiological norm by $4.76 \%(\mathrm{p} \leq 0.05)$ and was higher than in clinically healthy sheep by $22.08 \% \quad(\mathrm{p} \leq 0.05)$. This was evidenced by the results of taking into account its concentration in further biochemical studies, as a result of which it was established that the concentration of total bilirubin in the blood serum of clinically healthy sheep had a value of $7.38 \pm 2.24 \mathrm{mmol} / \mathrm{l}$, and in sheep with putrefactive decay of hooves $-9.01 \pm 1.03 \mathrm{mmol} / \mathrm{l}$. The urea concentration in all the examined patients was higher than the maximum permissible values of the physiological norm by $3.72 \%(\mathrm{p} \leq 0.05)$, and exceeded similar indicators in clinically healthy animals by $75.18 \%(\mathrm{p} \leq 0.05)$. Urea in the blood serum of sheep with putrefactive decay of hooves contained 9.46 \pm 0.23 $\mathrm{mmol} / \mathrm{l}$, and in clinically healthy animals $-5.40 \pm 1.20$ $\mathrm{mmol} / \mathrm{l}$. The quantitative content of glucose in the blood serum of clinically healthy sheep was $2.46 \pm 0.08 \mathrm{mmol} / \mathrm{l}$, and in sick sheep-2.02 $\pm 0.01 \mathrm{mmol} / \mathrm{l}$. Thus, by biochemical methods of analysis, it was established that putrefactive decay of hooves contributed to a decrease in glucose concentration by $17.88 \%(\mathrm{p} \leq 0.05)$, relative to
Figure 5. Hematocrit in healthy and sick animals, $\%$.

similar values in clinically healthy animals, and by $15.87 \%(\mathrm{p} \leq 0.05)$, relative to the maximum permissible concentrations of the physiological norm of this animal species. Analysis of the activity of enzymes in the blood serum of clinically healthy and sick sheep allowed us to determine the following indicators. Aspartate aminotransferase was $53.44 \pm 1.24 \mathrm{ed} / 1$ and $58.60 \pm 1.30$ $\mathrm{ed} / \mathrm{l}$; alanine aminotransferase $-35.47 \pm 1.42 \mathrm{ed} / \mathrm{l}$ and $38.72 \pm 2.31 \mathrm{ed} / \mathrm{l}$; alkaline phosphatase $-78.96 \pm 2.94 \mathrm{ed} / 1$ and $89.78 \pm 2.44 \mathrm{ed} / \mathrm{l}$; creatine kinase $-44.30 \pm 0.15 \mathrm{ed} / 1$ and $53.12 \pm 1.06 \mathrm{ed} / \mathrm{l}$, respectively. Interpretation of the obtained results of the activity of fermentases in the blood serum of clinically healthy sheep and sick sheep with putrefactive decay of hooves showed that in the latter category of animals, the activity of aspartate aminotransferase was higher than in the first by $9.65 \%$ $(\mathrm{p} \leq 0.05)$. A similar trend was observed with respect to other active fermentases taken into account, which indicated that putrefactive decomposition of hooves contributes to an increase in the activity of alanine aminotransferase by $9.16 \% \quad(\mathrm{p} \leq 0.05)$, alkaline phosphatase - by $13.70 \%(\mathrm{p} \leq 0.05)$, creatine kinase by $19.90 \%(\mathrm{p} \leq 0.05)$, relative to the reference activity indicators in clinically healthy animals. Taking into account macro- and microelements in the blood serum of healthy and sick sheep, it was revealed that putrefactive decay of hooves occurs against the background of a deficiency of sodium, calcium and phosphorus in the blood serum by $5.54 \%(\mathrm{p} \leq 0.05), 4.56 \%(\mathrm{p} \leq 0.05)$ and $3.53 \%(\mathrm{p} \leq 0.05)$. This is relative to the reference indicators of the physiological norm of this animal species. In addition, it was found that the level of sodium in the blood serum of sick sheep equal to $134.12 \pm 23.06$ $\mathrm{mmol} / \mathrm{l}$ was less than that in clinically healthy ones by $15.44 \%(p \leq 0.05)$. In them it is in the range of $158.62 \pm 18.31 \mathrm{mmol} / \mathrm{l}$. There was potassium in the blood serum of sick sheep $-4.12 \pm 0.06 \mathrm{mmol} / \mathrm{l}$ and it was less than that in clinically healthy animals by $9.64 \%$ $(\mathrm{p} \leq 0.05)$. In them, it contained $4.56 \pm 1.01 \mathrm{mmol} / \mathrm{l}$. Calcium and phosphorus in the blood of sheep with putrefactive decay of hooves were less than that in clinically healthy animals by $3.49 \% \quad(\mathrm{p} \leq 0.05)$ and $25.35 \%(\mathrm{p} \leq 0.05)$. Thus, their content level in healthy sheep was $2.72 \pm 0.36 \mathrm{mmol} / \mathrm{l}$ and $1.67 \pm 0.23 \mathrm{mmol} / \mathrm{l}$, and in sick animals $-2.68 \pm 0.33 \mathrm{mmol} / \mathrm{l}$ and $1.28 \pm 0.14$ $\mathrm{mmol} / \mathrm{l}$, respectively. Magnesium in the blood serum of 
sick animals was less than in clinically healthy animals by $9.78 \% \quad(p \leq 0.05)$, since in the first category of examined animals its concentration was in the range of $0.83 \pm 0.06 \mathrm{mmol} / \mathrm{l}$ and in the second $-0.92 \pm 0.01$ $\mathrm{mmol} / \mathrm{l}$

\section{Conclusion}

We have performed scientific studies to assess the effect of putrefactive decomposition of sheep hooves on the cellular composition, physical and chemical properties of blood, on the biochemical composition of its serum. It has allowed us to establish that in sick animals, a decrease in the quality of red blood cells and platelets is recorded by $28.94 \%(\mathrm{p} \leq 0.05)$ and $4.13 \%(\mathrm{p} \leq 0.05)$. The concentration of hemoglobin decreased by $22.88 \%$ $(\mathrm{p} \leq 0.05)$, the hematocrit value - by $8.80 \%(\mathrm{p} \leq 0.05)$. The average content of hemoglobin in the blood increased in the number of white blood cells by $23.98 \%(\mathrm{p} \leq 0.05)$, as well as the number of white blood cells - by $89.13 \%$ $(\mathrm{p} \leq 0.05)$. And the rate of erythrocyte sedimentation increased by $44.70 \% \quad(\mathrm{p} \leq 0.05)$, relative to similar hematological parameters of clinically healthy sheep. Biochemical methods of blood serum analysis revealed that putrefactive decomposition of sheep hooves contributed to an increase in the concentration of total protein by $7.94 \%(\mathrm{p} \leq 0.05)$, total bilirubin - by $22.08 \%$ $(\mathrm{p} \leq 0.05)$, urea by $75.18 \% \quad(\mathrm{p} \leq 0.05)$. The glucose concentration increased by $17.88 \%(\mathrm{p} \leq 0.05)$ more than that in clinically healthy sheep. At the same time, the activity of aspartate aminotransferase, alanine aminotransferase, alkaline phosphatase, and creatine kinase in blood serum in sick sheep exceeded similar indicators in clinically healthy animals by $9.65 \%$ $(\mathrm{p} \leq 0.05), 9.16 \%(\mathrm{p} \leq 0.05), 13.70 \%(\mathrm{p} \leq 0.05)$, and $19.90 \%$ $(\mathrm{p} \leq 0.05)$, respectively. In addition, the blood serum of sheep with putrefactive hoof decay was found to be deficient in sodium, potassium, and phosphorus by $5.54 \%(\mathrm{p} \leq 0.05), 4.56 \%(\mathrm{p} \leq 0.05)$, and $3.53 \%(\mathrm{p} \leq 0.05)$ relative to the reference parameters of the physiological norm. At the same time, sodium, potassium, calcium, phosphorus and magnesium in the blood serum of sheep with putrefactive decomposition of hooves contained by $15.44 \% \quad(\mathrm{p} \leq 0.05), 9.64 \% \quad(\mathrm{p} \leq 0.05), 3.49 \% \quad(\mathrm{p} \leq 0.05)$, $25.35 \%(\mathrm{p} \leq 0.05)$ and $9.78 \%(\mathrm{p} \leq 0.05)$ less than in sheep without putrefactive decomposition of hooves.

\section{References}

1. M. Akrami, Z. H. Qian, Z. M. Zou, D. Howard, C. J. Nester, L. Ren Biomech. Model. in Mechanobiol. 17, 559-576, (2018).

2. X. Liu, Y. Y. Yang, X. M. Wang, Z. S. Liu, Z. H. Wang, Y. Z. Ding Genet. Mol. Res. 14 (3), 713750 (2015)

3. Y. Zhang, W. Huang, C. Hayashi, J. Gatesy, J. McKittrick J. R. Soc. Interface 24, 1713-1750 (2018)

4. S.M. Kolomiytsev, V.A. Tolkachev, N.V. Vanina, A.S. Polyansky Bulletin of Kursk State Agricultural Academy. 8, 25 - 28 (2017).
5. A.N. Eliseev, S.M. Kolomiytsev, A.I. Blednov, V.N. Suvorova, D.N.Boldyrev, V.A. Tolkachev, T.A. Ekimova Bulletin of Kursk State Agricultural Academy. 1, 63 - 66, (2015)

6. A.N. Eliseev, S.M. Kolomiytsev, A.I. Blednov, V.A. Tolkachev, D.N. Boldyrev, E.A. Steblovsky Bulletin of Kursk State Agricultural Academy. 9, 71 - 74, (2013).

7. A.S. Polyansky, A.N. Eliseev, V.A. Tolkachev Scientific support of agro-industrial production. Materials of the International Scientific and Practical Conference. P. 56-60, (2018). 